\title{
First record of Diamesa thomasi Serra-Tosio, 1970, from Croatia
}

\author{
Viktor Baranov $^{1}$, Marija Ivković ${ }^{2}$, and Endre Willassen ${ }^{3}$ \\ ${ }^{1}$ I.I. Schmalhausen Institute of Zoology, NAS, Kiev, Ukraine. \\ E-mail: baranowiktor@gmail.com \\ ${ }^{2}$ Department of Zoology, University of Zagreb, Croatia \\ E-mail: marija.ivkovic@biol.pmf.hr \\ ${ }^{3}$ University Museum of Bergen, Norway \\ E-mail: endre.willassen@um.uib.no
}

Plitvice National Park is situated in the mountainous karst area of Croatia. When conducting studies of the chironomid fauna of the park, we found that Diamesa thomasi Serra-Tosio, 1970 were abundant in the stream Bjela rijeka. The streams Bijela rijeka and Crna rijeka form the Matica River, which is the main surface-water supplier of the lakes in the park. This is the first record of $D$. thomasi in Croatia. The river's source, the Bijela rijeka spring, is located at an altitude of $719 \mathrm{~m}$ a.s.l. at $44^{\circ} 50^{\prime} 05^{\prime \prime} \mathrm{N}$ and $15^{\circ} 33^{\prime} 43^{\prime \prime} \mathrm{E}$. The Bijela rijeka spring is a rheocrene that dries out only during extremely dry years (Marušić \& Ćuruvija 1991). Spring water emerges from substrate composed mainly of cobbles and sand with a few interspersed moss-covered boulders. Because of these characteristics, it is considered a psammorheocrene type of spring (Gerecke et al. 1998). The tree canopy is open during spring, and there is much aquatic vegetation and accumulated allochthonous organic material during autumn and winter.

A pyramid-type emergence trap was operated at six locations from February 2007 to February 2008. Diamesa thomasi was recorded at three of them. In total, we have collected 94 adult specimens of $D$. thomasi from these traps. Maximum number of specimens collected at one time is 48 . All specimens were found in winter / spring samples with the emergence period ranging from November until May.

Serra-Tosio (1970) considered D. thomasi as a member the dampfi group with Diamesa dampfi (Kieffer, 1924) as sister species and Diamesa permacra (Walker, 1856) as their closest relative. These midges are characterized by the combination of a typical Diamesa wing and a flattened, but not completely cordiform fourth tarsi (Fig. 1A). We used Sanger-sequencing on frequently used DNA markers, including mitochondrial cytochrome $c$ oxidase subunits I and II (COI, COII) (e.g. Ekrem et al., 2010) to quickly check for relationships between $D$. thomasi and 55 other Diamesinae species (Willassen unpublished data). Three specimens were prepared for DNA analysis according to the procedure described by Ekrem et al. (2010) and vouchers are kept in the collections of Bergen University Museum. Unfortunately, the standard DNA barcoding primers (Folmer et al. 1994) did not yield clean sequences with unambiguous base calls for COI. However, the COII segment places D. thomasi as sister to D. permacra in the dataset. Unfortunately, the dataset currently lacks sequences from $D$. dampfi.

Morphologically, the male genitalia of D. thomasi (Figs. 1C-D) correspond with the description by SerraTosio (1970, figs. 8, 9). Serra-Tosio (1970) also included a figure of the female genitalia in lateral view and Willassen and Serra-Tosio (1988, figs. 3.4, 3.6) showed that the hypothetical sister species, D. dampfi (Kieffer, 1924) differs from $D$. thomasi by possessing a long and digitiform gonocoxite IX. In ventral view (Figs. $1 \mathrm{E}-\mathrm{F}$ ) the female genitalia of $D$. thomasi appear more similar to D. permacra (see Willassen 1982, fig. 10.2).

This study is important in that it expands the known distribution of $D$. thomasi. Since its first discovery in the French Pyrenées (Serra-Tosio 1970), and with additional findings in the region by Moubayed-Breil (2007), the distribution of $D$. thomasi is presently known to range from the Caucasus Mountains, the Tatra Mountains and Carpathians (Kownacki and Kownacka 1974; Kownacki 1988), to the Dinaric Mountains in Croatia. Diamesa thomasi has also been recorded from the Thuringian Forest in Germany (Bellstedt 1992).

\section{Acknowledgements}

We are most grateful to Dr. Louise Lindblom and the University of Bergen sequencing facility at HiB for help with producing DNA sequences. Thanks to Martin Spies for the reference to the record from Germany. Viktor Baranov's work with University of Bergen Chironomidae collection was supported by an Ernst Mayer travel grant (Harvard Museum of Comparative zoology). 


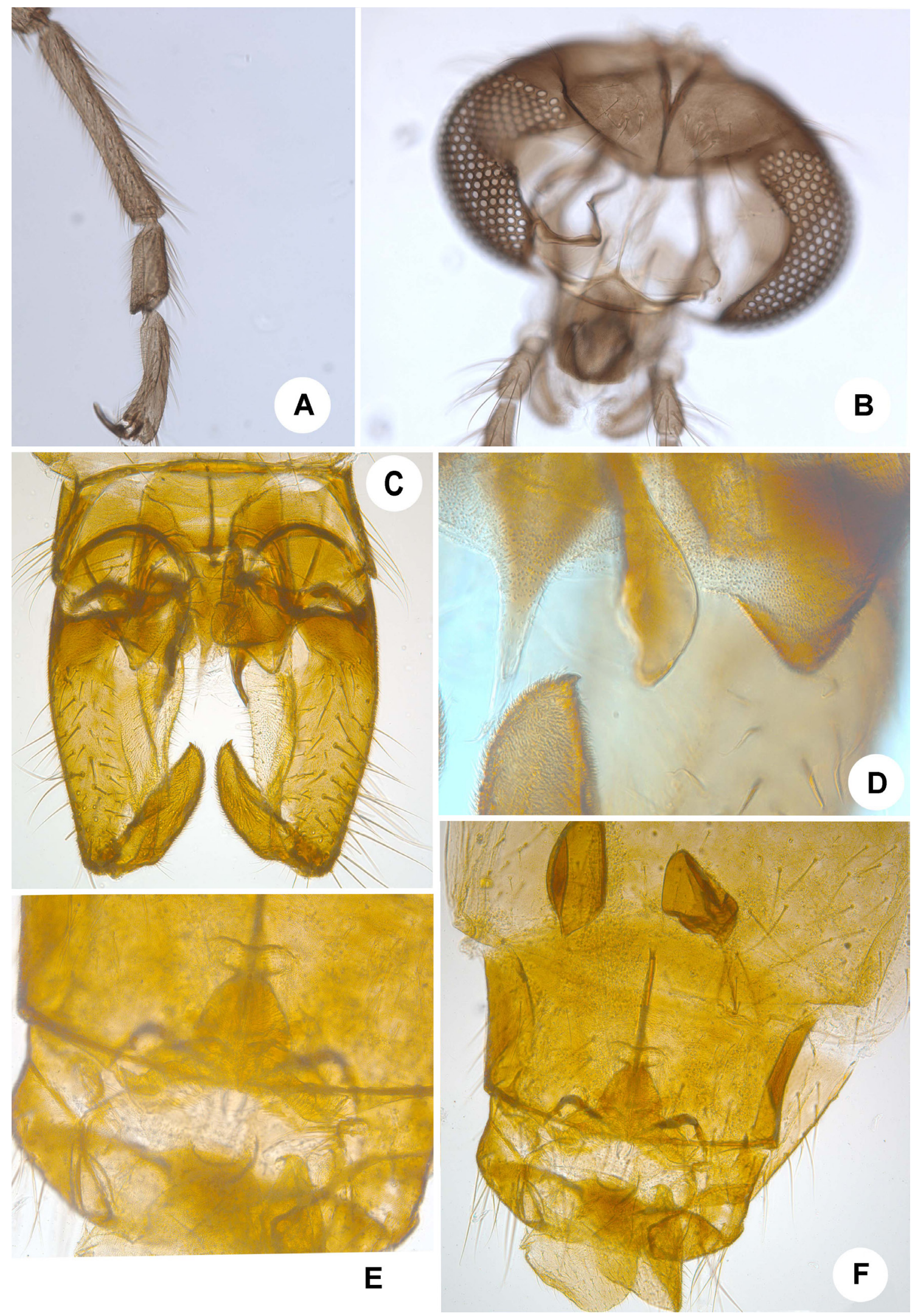

Figure 1. Diamesa thomasi Serra-Tosio, 1970 from Croatia. A. leg with typical shape of tarsus four; B. male head; C. male genitalia; D. details of male genitalia; E. female genitalia in ventral view; F. female genitalia with seminal capsules. 


\section{References}

Bellstedt, R. 1992. Schneeinsekten im Thüringer Wald - ein Beitrag zum Gedenken an den Gothaer Insektenforscher Gustav Jänner. - Abhandlungen und Berichte des Museums der Natur Gotha 17: 88.

Gerecke, R., Meisch, C., Stoch, F., Acri, F. and Franz, H. 1998. Eucrenon-hypocrenon ecotone and spring typology in the Alps of Berchtesgaden (Upper Bavaria, Germany): A study of microcrustacea (Crustacea: Copepoda, Ostracoda) and water mites (Acari: Halacaridae, Hydrachnellae), In Botosaneanu L. (Ed.) Studies in Crenobiology. The biology of springs and springbrooks. Backhuys Publishers, Leiden. pp. 167-182.

Ekrem, T., Willassen, E. and Stur, E. 2010. Phylogenetic utility of five genes for dipteran phylogeny: A test case in the Chironomidae leads to generic synonymies. - Molecular Phylogenetics and Evolution 57: $561-571$

Folmer, O., Black, M., Hoeh, W., Lutz, R. and Vrijenhoek, R. 1994. DNA primers for amplification of mitochondrial cytochrome $\mathrm{C}$ oxidase subunit I from diverse metazoan invertebrates. - Molecular Marine Biology and Biotechnology 3: 294-299.

Kownacki, A. and Kownacka, M. 1974. Relation of Chironomidae from Tatra and the Caucasus Mts. - Entomologisk Tidskrift Supplement 95: 129-138.

Kownacki, A. 1987. Ecology and biogeography of Diamesinae (Chironomidae, Diptera) in Poland. - Acta Universitatis Lodziensis, Folia Limnologica 2: 3-25.

Marušić, R. and Ćuruvija, M. 1991. Istraživanja podzemnih vodenih veza Nacionalnog parka Plitvička jezera. - Plitvički bilten 3-4: 19-29.

Moubayed-Breil, M. 2007. New records of Chironomidae (Diptera) from Continental France. CHIRONOMUS Newsletter on Chironomidae Research 20: 36-42.

Serra-Tosio, B. 1970. Les Diamesa du groupe dampfi. Description d'une espèce nouvelle (Diptera, Chironomidae). - Travaux du Laboratoire d'hydrobiologie et de pisciculture de l'Université de Grenoble 61: 107-146

Serra-Tosio, B. 1970. Contribution à l'étude taxonomique, phylogénétique, biogéographique et écologique des Diamesini (Diptera, Chironomidae) d'Europe. Thèse Université scientifique et médical de Grenoble. pp. 1-103, pp. 304- 462.

Willassen, E. 1982. Descriptions and redescriptions of female Diamesa Meigen, 1835 (Diptera: Chironomidae); with a comparative morphology, keys, phylogenetic and biogeographical notes. Doctoral Thesis, University of Bergen. pp. 1-316.

Willassen, E. and Serra-Tosio, B. 1988. Description de trois femelles de Diamesa Meigen dont D. cinerella Meigen (lectotype et paralectotype) (Diptera, Chironomidae). - Spixiana Supplement 14: 91-100. 